Eurasian Journal of Business and Economics, 14(27), 63-75, (2021).

\title{
Does the Export-Led Growth Hypothesis Hold for Services Exports in Emerging Economies?
}

\author{
Okpeku Lilian ONOSE*, Osman Nuri ARAS**
}

Received: April 7, 2021

Revised: May 29, 2021

Accepted: May 30, 2021.

\begin{abstract}
The export-led growth hypothesis states a positive relationship between the growth of exports and long-run economic growth. This study examines the validity of the export-led growth hypothesis of services exports in 5 emerging economies, including Brazil, India, Nigeria, China, and South Africa (BINCS), for the period of 1980-2019. The study employs the panel mean group autoregressive distributed lag (ARDL) procedure to identify a causal relationship between services exports and gross domestic product (GDP) per capita. The findings show that the export-led growth hypothesis in services only has a positive effect on economic growth in the short run while other variables, including foreign direct investment (FDI), gross capital formation, and labour, increase economic growth in the long run. Hence, the emerging countries should focus more on internal investment to boost growth in the long and short run.
\end{abstract}

Keywords: Exports, Economic Growth, Export-Led Growth, Services Exports, Emerging Economies.

JEL Code Classifications: F13, F43, N70, 024

UDC: 339.5

DOI: https://doi.org/10.17015/ejbe.2021.027.04.

\footnotetext{
* Corresponding Author, PhD Candidate, Nile University of Nigeria, Abuja, Nigeria. E-mail: lilianokpeku@gmail.com

** Prof. Dr., Nile University of Nigeria, Abuja, Nigeria.E-mail: osmannuriaras@nileuniversity.edu.ng

Copyright @ , 2021 Ala-Too International University.
} 


\section{Introduction}

A major desire of every country to promote its economic growth is the reason economists have focused on the examination of the export-led growth (ELG) hypothesis. The export-led growth hypothesis is among the most argued discussion, and it asserts a positive relationship between exports and real GDP growth in the long run. This implies a shift from import substitution and to export promotion with increased trade openness. According to this hypothesis, economic growth depends on not only the increase in the number of labours and the amount of capital stock, but also on the growth of exports through a multiplier effect.

Starting from the earlier studies of Balassa (1978) and (1985), empirical investigations have continued to examine the compatibility and validity of the export-led growth (ELG) hypothesis for developed and developing countries.

Since emerging economies including Brazil, India, Nigeria, China, and South Africa began to expand in international trade, their economies have been met by an increase in exports as a percentage of GDP, leading to rapid economic growth. Various studies were carried out to examine if the increase were export-led or growth-led, and mixed results have been presented. Islam (2020) tested this hypothesis in India and China using a panel causality test and found that export has a positive impact on growth in the long run. Similarly, Feddersen et al. (2017) examined the impact of export on economic growth in South Africa using variance decomposition analysis and Granger causality tests. The analysis showed that export has a positive effect on economic growth only in the short run with an unidentified effect in the long run.

One major aspect of the studies on the ELG hypothesis in emerging economies is the focus of researchers on merchandise export and financial exports. Very few research emphasises the rapid dynamic effect of the service sectors in recent years. Trade-in services have been expanding at a faster rate than trades in goods. According to World Trade Organization (WTO, 2021), services in the aforementioned emerging economies have increased at an average of $3 \%$ annually since 2008 . The potential of the service sector as a major source of foreign earnings has had minimal focus by researchers on the examination of the ELG hypothesis. Shieh (2020) highlighted that just as trade in goods, service trade could contribute to a more efficient allocation of resources and improving firms' competitiveness in the services sector. Services in world trade in value-added terms accounted for $64.9 \%$ of world trade.

Due to the growing nature of services in developing countries, the aim of this paper is to examine the relationship between services exports and economic growth for five emerging economies, including Brazil, India, Nigeria, China, and South Africa (BINCS), for the period of 1980-2020. The study contributes to existing research by providing a new analysis on services exports and economic growth in emerging economies. The remainder of this paper is as follows; section two introduces the 
literature review; section three presents the empirical model and data used. Then section four presents the empirical results, and section five contains the conclusions.

\section{Review of Literature}

\subsection{Theoretical Framework}

The idea that the relationships between exports and economic growth are not a new idea. Theoretically, the relationship between exports and economic growth has been linked to potential positive externalities arising from foreign markets. According to the export-led growth hypothesis, the growth of exports has a stimulating effect on the economy in the form of technological spillovers and other externalities.

Helpman and Krugman (1985) assume that the growth of export leads to real GDP growth through specialization in production, economies of scale, as well as distribution of technical knowledge: International trade openness provides to increase efficiency and to an incentive for product and process innovation, and the increase in specialization allows the exploitation of economies of scale. The growth of exports contributes to the stock of knowledge and human capital in the economy; thereby, all firms benefit from them.

On the other hand, Carbaugh (2015) mentions that as a development strategy, export-led growth hypothesis, in other words, export-oriented policy, has three major advantages; encouraging industries in which developing countries are likely to have a comparative advantage, providing domestic manufacturers greater scope for exploiting economies of scale and imposing a competitive discipline on domestic firms that force them to increase efficiency.

\subsection{Review of the Empirical Literature}

In the past 40 years, the majority of the ELG researches have shown a positive relationship between exports and economic growth. On the other hand, according to the most recent empirical evidence, there have been mixed and inconclusive results between exports and economic growth for various countries.

Most of the studies focus on developing countries; several studies have examined the ELG hypothesis for developed countries. On the other hand, some studies found empirical evidence in support of the ELG hypothesis; other empirical evidence indicated a bidirectional causal relationship:

Awokuse (2003) examined the export-led growth (ELG) hypothesis for Canada by using the Granger causality test, vector error correction models (VECM), and the augmented vector autoregressive (VAR) model. The empirical results of this study show that a long-run steady-state exists among the model's variables and that Granger causal flow is unidirectional from real exports to real GDP.

Taban and Aktar (2008) examined the export-led growth hypothesis by applying the cointegration and error correction procedures for the period 1980-2007 in Turkey. 
Their empirical results support the hypothesis that there is a long-run and short-run bidirectional causality relationship between export growth and real GDP growth in Turkey. Aslan and Topcu (2018) also investigated the export-led growth hypothesis in Turkey using disaggregated data and employing the Granger causality test. Their result showed strong backing for the manufacturing ELG hypothesis.

Kalaitzi and Chamberlain (2020) also investigated the cogency of the ELG hypothesis in some GCC (The Gulf Cooperation Council) countries using a VAR model and Johansen cointegration test. Their empirical result does not support ELG hypothesis as it states that export affects economic growth only in the short run while economic growth causes exports in the long run.

Similarly, Kollie (2020) on selected ECOWAS (the Economic Community of West African States) member states implementing disaggregated exports into merchandise exports, services exports and total exports from 2000-2017 showed that from panel ARDL estimation, merchandise export does not affect economic growth in the long but services exports lead to economic growth in the long run.

Dixit and Parveen (2020) investigated the export-growth nexus from the supply-side and the demand-side perspective using the lag-augmented vector autoregressive non-causality test. Their results showed a positive impact of services and manufacturing exports on economic growth. However, only the impact of manufacturing was significant. In particular to agriculture, Kappa (2020) examined whether vegetable export leads to economic growth in selected south Asian countries. Using Johansen-Fisher cointegration and fully modified ordinary leastsquares (OLS) regression model, the analysis confirmed that vegetable exports lead to economic growth in the long run alone.

Seyram-Asafo (2020) employed the use of the threshold VAR model and the twothreshold vector error correction model (VECM) in order to conduct a non-linearity test for the ELG hypothesis in Ghana from 1970-2018. The results show that supported by the two models, and export has a significant long-term positive impact on economic growth.

lyabo (2020) also examined the non-oil impact of export on economic growth in Nigeria from 1984-2015 using a vector autoregression model. The results showed that non-oil exports affect economic growth both directly and indirectly through other variables such as foreign debt, external reserves, terms of trade, and investment.

Considering the few studies that have investigated the service ELG hypothesis, Priyankara (2018) investigated the hypothesis for Sri Lanka using Granger noncausality procedure in a Vector Autoregressive model from 1984-2013. The results showed a one-way causality from the exports of services to output growth in Sri Lanka. 
Kalaitzi and Cleeve (2018) studied the validity of the ELG hypothesis in the United Arab Emirates (UAE) for the period of 1981-2012 by using the Johansen cointegration test, the multivariate Granger causality test, and a modified version of the Wald test and focusing on the causality between primary exports, manufactured exports and economic growth. The result of this study provides evidence to support a bidirectional causality between manufactured exports and economic growth in the short run, while the hypothesis is valid in the long run for UAE.

Similarly, Sermcheep (2019) used a disaggregated annual data set into modern and traditional services exports for 192 countries from 1970-2014, and the results from panel FE and RE model reveal that services exports, modern and traditional, have a significant positive effect on economic growth and traditional services exports could serve as an engine for economic growth.

Shieh (2020) also attempted to investigate this hypothesis for services in 89 countries using ECM and OLS methods. Their analysis reveals a long-run causality from exports in services to income, thus substantiating the service export-led growth hypothesis.

Aigheyisi (2020) also investigated the service ELG hypothesis in Nigeria from 19812018 using ARDL modelling. According to their results, the ELG hypothesis for the service sector does not hold in Nigeria in both the short and long run.

Odhiambo (2021) examined the relationship between exports and economic growth in sub-Saharan African (SSA) countries for the period of 1980-2017 using a panel cointegration test and panel Granger-causality model. The study found the existence of a long-run relationship between exports and economic growth. On the other hand, while the study didn't find any export-led growth response in both low-income and middle-income countries, it found evidence of a bidirectional causality and a neutrality response in middle-income and low-income countries, respectively.

This study adds to the literature by testing the service export-led growth hypothesis in emerging economies. It examines the service ELG hypothesis by testing the longrun export-income relationship by uniquely using panel-mean group ARDL estimation

\section{Empirical Model}

This research examines the validity of the service export-led growth hypothesis by adopting the basic idea for the econometrics model specification taken from Shieh 2020 and Kalaitzi and Chamberlain (2020). The authors tested the export-led growth hypothesis of services using four variables, including real GDP, real services exports, real capital stock, and labour. The empirical model in this study starts with a simple neoclassical production function;

$$
Y=A_{t} K_{t}^{\alpha} L_{t}^{\beta}
$$

Where;

$Y_{t}=$ denotes the aggregate production of the economy at time $t$, 
$A=$ Total Factor Productivity,

$K_{t}, L_{t}=$ levels of capital stock and labour,

$\alpha$ and $\beta=$ constants $(0<\alpha$ and $\beta<1)$

This paper further estimates the augmented Cobb-Douglas function (see: Douglas,1976), which includes exports as proposed by growth theories and the Total Factor Productivity (TFP). TFP is the additional output generated through enhancements in the efficiency accounted for by things such as innovation, trade, human capital, technology transfer, skills and training, and others. Therefore, it is important to include disaggregation of exports and the inclusion of services exports which is a key factor of explaining services TFP (Van der Marel 2012). The econometric model of this relationship is represented as follows;

$$
G D P C_{i t}=\alpha_{i}+\beta_{1} x_{i t}+\gamma_{i} k_{i t}+\delta_{i} l_{i t}+\theta_{i} f d i_{i t}+\mu_{i t}
$$

Where $y_{i t}$ is the log of the GDP per capita, $x_{i t}$ is the log of real services exports, $k_{i t}$ is the log of gross capital formation, $l_{i t}$ is the log of labour, $f d i_{i t}$ is the log of foreign direct investment and $\gamma, \delta$ and $\theta$ are cointegrated with slopes $\beta$. For ELG hypothesis to hold under the null hypothesis $H_{0}: \beta_{i}=0$ for all $\mathrm{i}$.

Transforming this into a log-linear equation, we have equation (3) below;

$$
\begin{aligned}
L_{N G D P C}= & \alpha_{i}+\beta_{1} \text { LNServiceexport }_{i t}+\gamma_{i} \text { LNGCapitalformation }_{i t}+ \\
& \delta_{i} \text { LNLabour }_{i t}+\theta_{i} \text { LNFDI }_{i t}+\mu_{i t}
\end{aligned}
$$

\subsection{Data and Sources}

The analysis of this study covers a panel group of 5 countries covering from 19802019 due to the availability of data. To achieve this investigation, data is sourced from the world development indicators (WDI)

The panel data consists of annual observations on GDP per capita, services exports, FDI, labour force participation, and gross fixed capital formation. The countries included are Brazil, India, Nigeria, China, and South Africa.

We use GDP per capita as a preferred measure of growth since it captures the nation's standard of living. The service export captures the export of services from the emerging economies in the current US Dollars value. Similarly, the Gross capital formation (which stands as a proxy for capital) and Foreign Direct Investment (FDI) are measured in current US Dollar values of domestic capital. Labour force participation represents the total of the working population in BNICS.

\subsection{Estimation Techniques}

In order to achieve the aim of this study which is to investigate the relevance of the service export-led growth hypothesis, we employ the use of Panel Mean Group Autoregressive Distributed Lags (ARDL/PMG) to estimate the econometric model. This method is best due to its various advantages over other methods. Firstly, it allows us to estimate the short and long-run, and short-run coefficients even with a 
small sample size like in this paper. The approach also has the added benefit of providing consistent estimates of the long-run coefficients that are asymptotically normal, notwithstanding whether the underlying regressors are stationary at first differencing or stationary series without differencing (Pesaran \& Shin, 2001). Another attractive feature of the panel ARDL is its usefulness when variables have mixed order of integration, such as I(0), I(1), or both (Kollie 2020).

\subsection{Descriptive Statistics}

Table 1 present a summarized descriptive statistic of the variables in the overall panel group. An investigation of the variables shows that the real gross domestic product per capita has an average value of USD3,884 in the BINCS countries. This average per capita income falls within the range of USD400 and USD13,246. Foreign direct investment recorded an average value of USD44.1 billion, gross capital formation USD654 billion, services exports USD52.7 billion, and a total of 273 million people are part of the labour force on average within the period of consideration in BINCS countries. The standard deviation reveals that all the series show a moderate degree of variation from their mean. Moreover, Jarque-Bera's statistics for all the variables are significant at the $1 \%$ level. Therefore, the series is not normally distributed. By implication, to avoid spurious regression, the other properties of the series, such as the stationarity property, are examined below.

Table 1. Summary Statistics

\begin{tabular}{lrrrrrr}
\hline Var & Obs & \multicolumn{1}{c}{ Mean } & \multicolumn{1}{c}{ Std. Dev. } & \multicolumn{1}{c}{ Min } & \multicolumn{1}{c}{ Max } & Jarque-Bera \\
\hline GDPC & 120 & $3,884.134$ & $3,246.800$ & 399.9501 & $13,245.61$ & $179.76^{* * *}$ \\
\hline FDI & 120 & $44,100,000,000$ & $66,700,000,000$ & $300,000,000$ & $291,000,000,000$ & $461.20^{* * *}$ \\
\hline GCF & 120 & $654,000,000,000$ & $1,300,000,000,000$ & $18,700,000,000$ & $6,200,000,000,000$ & $18.29^{* * *}$ \\
\hline LBF & 120 & $273,000,000$ & $290,000,000$ & $14,944,259$ & $787,000,000$ & $16.95^{* * *}$ \\
\hline SEXP & 120 & $52,700,000,000$ & $67,900,000,000$ & $230,000,000$ & $244,000,000,000$ & $42.62^{* * *}$ \\
\hline
\end{tabular}

Source: Authors computation from EViews $10 * *$ p-value $<0.01,{ }^{* *}$ p-value $<0.05,{ }^{*}$ p-value $<0.1$

Table 2 shows the correlation matrix that reveals the expected sign between the natural logarithm of real GDP per capita and other series. The natural logarithm of real gross domestic product per capita and the natural log of FDI, natural log of gross capital formation, and the natural logarithm of services exports exhibit a positive correlation while natural logarithm of real gross domestic per capita and logarithm of labour force exhibit a negative correlation.

Table 2. Correlation Matrix

\begin{tabular}{l|rrrrr}
\hline & LDPDC & LFDI & LGCF & LLBF & LSEXP \\
\hline LDPDC & 1 & & & & \\
\hline LFDI & 0.402173 & 1 & & & \\
\hline LGCF & 0.263412 & 0.904726 & 1 & & \\
\hline LLBF & -0.269653 & 0.710830 & 0.844413 & 1 & 1 \\
\hline LSEXP & 0.261112 & 0.802919 & 0.886477 & 0.741986 & \\
\hline
\end{tabular}

Source: Authors computation from EViews 10 


\subsection{Unit Root Analysis}

Table 3 and 4 presents the stationarity test result to evaluate the unit root properties of the series following the presence of abnormality in the distribution of the series and the co-integration test results using the Pedroni and Kao co-integration test, respectively. Applying the ADF-Fisher, Levin, Lin, and Chu, and Im, Pesaran, and Shin (IPS) for the unit root test, findings show that the series exhibit a mixed level of stationarity. Services exports, gross capital formation, and labour force are stationary at the level given the Levin, Lin, and Chu test. Moreover, Im, Pesaran, and Shin (IPS), and ADF-fisher show that all the series except labor force are stationary after the first difference. The implication of this result is that the series exhibit constant variance and mean reversion which are important properties of the analysis to avoid a spurious regression.

\section{Table 3. Results of Panel Unit Root Tests}

\begin{tabular}{|c|c|c|c|c|c|c|}
\hline \multirow{2}{*}{$\begin{array}{c}\text { Test } \\
\text { Variable }\end{array}$} & \multicolumn{2}{|c|}{ IPS } & \multicolumn{2}{|c|}{ ADF-FISHER } & \multicolumn{2}{|c|}{ Levin, Lin \& Chu t* } \\
\hline & Constant & $\begin{array}{l}\text { Constant } \\
\text { and Trend }\end{array}$ & Constant & $\begin{array}{l}\text { Constant } \\
\text { and Trend }\end{array}$ & Constant & $\begin{array}{l}\text { Constant } \\
\text { and Trend }\end{array}$ \\
\hline LGDPC & $\begin{array}{l}1.01044 \\
(0.8439)\end{array}$ & $\begin{array}{l}1.43094 \\
(0.9238)\end{array}$ & $\begin{array}{l}4.19383 \\
(0.9382)\end{array}$ & $\begin{array}{l}3.38503 \\
(0.9709)\end{array}$ & $\begin{array}{r}-1.11224 \\
(0.1330)\end{array}$ & $\begin{array}{l}1.09010 \\
(0.8622)\end{array}$ \\
\hline LSEXP & $\begin{array}{l}0.68666 \\
(0.2461)\end{array}$ & $\begin{array}{l}1.24484 \\
(0.8934)\end{array}$ & $\begin{array}{l}11.5884 \\
(0.3135)\end{array}$ & $\begin{array}{l}7.39832 \\
(0.6874) \\
\end{array}$ & $\begin{array}{c}-2.42275 \\
(0.0077)^{b}\end{array}$ & $\begin{array}{l}1.31222 \\
(0.9053)\end{array}$ \\
\hline LFDI & $\begin{array}{l}-0.06026 \\
(0.4760)\end{array}$ & $\begin{array}{l}1.47116 \\
(0.9294)\end{array}$ & $\begin{array}{l}8.25355 \\
(0.6041)\end{array}$ & $\begin{array}{l}5.43930 \\
(0.8600)\end{array}$ & $\begin{array}{r}-1.04687 \\
(0.1476)\end{array}$ & $\begin{array}{l}1.18817 \\
(0.8826)\end{array}$ \\
\hline LGCF & $\begin{array}{l}0.99853 \\
(0.8410) \\
\end{array}$ & $\begin{array}{l}1.48494 \\
(0.9312) \\
\end{array}$ & $\begin{array}{l}3.87288 \\
(0.9529) \\
\end{array}$ & $\begin{array}{l}3.73547 \\
(0.9585) \\
\end{array}$ & $\begin{array}{c}-1.39938 \\
(0.0809)^{b} \\
\end{array}$ & $\begin{array}{l}1.23151 \\
(0.8909) \\
\end{array}$ \\
\hline LLBF & $\begin{array}{l}0.13498 \\
(0.5537)\end{array}$ & $\begin{array}{l}0.36544 \\
(0.6426)\end{array}$ & $\begin{array}{l}11.0010 \\
(0.3574)\end{array}$ & $\begin{array}{l}8.85546 \\
(0.5459)\end{array}$ & $\begin{array}{l}-2.25568 \\
(0.0120)^{b}\end{array}$ & $\begin{array}{c}-1.31340 \\
(0.0945)^{b}\end{array}$ \\
\hline$\triangle \mathrm{LGDPC}$ & $\begin{array}{c}-2.34737 \\
(0.0095)^{b} \\
\end{array}$ & $\begin{array}{r}-1.03087 \\
(0.1513) \\
\end{array}$ & $\begin{array}{c}21.9585 \\
(0.0153)^{b} \\
\end{array}$ & $\begin{array}{l}13.7113 \\
(0.1866) \\
\end{array}$ & $\begin{array}{c}-2.79819 \\
(0.0026)^{b}\end{array}$ & $\begin{array}{l}-2.42133 \\
(0.0077)^{b}\end{array}$ \\
\hline$\Delta$ LSEXP & $\begin{array}{l}-3.58965 \\
(0.0002)^{b} \\
\end{array}$ & $\begin{array}{r}-2.69257 \\
(0.0035)^{\mathrm{b}} \\
\end{array}$ & $\begin{array}{c}31.4529 \\
(0.0005)^{b} \\
\end{array}$ & $\begin{array}{c}23.8529 \\
(0.0080)^{b} \\
\end{array}$ & $\begin{array}{r}-3.66126 \\
(0.0001)^{b} \\
\end{array}$ & $\begin{array}{r}-3.26966 \\
(0.0005)^{b} \\
\end{array}$ \\
\hline$\Delta \mathrm{LFDI}$ & $\begin{array}{l}-5.13219 \\
(0.000)^{\mathrm{b}}\end{array}$ & $\begin{array}{l}-5.75532 \\
(0.000)^{b}\end{array}$ & $\begin{array}{l}44.3193 \\
(0.000)^{\mathrm{b}}\end{array}$ & $\begin{array}{l}47.3915 \\
(0.000)^{b}\end{array}$ & $\begin{array}{l}-1.32867 \\
(0.0920)^{b}\end{array}$ & $\begin{array}{c}-1.74411 \\
(0.0406)^{b}\end{array}$ \\
\hline$\Delta \mathrm{LGCF}$ & $\begin{array}{c}-2.13781 \\
(0.0163)^{b} \\
\end{array}$ & $\begin{array}{r}-0.68995 \\
(0.2451) \\
\end{array}$ & $\begin{array}{c}19.4371 \\
(0.0350)^{b} \\
\end{array}$ & $\begin{array}{l}11.0571 \\
(0.3531) \\
\end{array}$ & $\begin{array}{c}-2.38410 \\
(0.0086)^{b}\end{array}$ & $\begin{array}{r}-2.10106 \\
(0.0178)^{b}\end{array}$ \\
\hline$\Delta \mathrm{LLBF}$ & $\begin{array}{l}-0.60866 \\
(0.2714)\end{array}$ & $\begin{array}{c}-0.50911 \\
(0.3053)\end{array}$ & $\begin{array}{l}12.3094 \\
(0.2649)\end{array}$ & $\begin{array}{l}11.3021 \\
(0.3345)\end{array}$ & $\begin{array}{l}-0.96327 \\
(0.1677)\end{array}$ & $\begin{array}{c}-0.72803 \\
(0.2333)\end{array}$ \\
\hline
\end{tabular}

Notes: LGDPC, LSEXP, LFDI, LGCF, and LLBF implies logarithm of GDP per capita, services exports, FDI, gross capital formation, and labour force. $\Delta$ is first difference operator. The AIC and Hannan-Quinn were used to determine the lag lengths. b. Rejection of the null hypothesis of "unit root" at the $10 \%$ level of significance; probability values in parentheses.

Source: Authors computation from the output of EViews 10. 
Does the Export-Led Growth Hypothesis Hold for Services Exports in Emerging Economies?

Table 4. Results of Panel Unit Root Tests

\begin{tabular}{|l|c|c|}
\hline Test & \multicolumn{2}{|c|}{ Pedroni Residual Co-integration Test } \\
\hline Trend Assumption & Deterministic Intercept and Trend & No deterministic Trend \\
\hline Alternative hypothesis: common AR coefficients (within-dimension) \\
\hline Panel v-Statistic & $-0.777833(0.7817)$ & $0.044213(0.4824)$ \\
\hline Panel rho-Statistic & $-1.078371(0.1404)$ & $-1.584466(0.0565)$ \\
\hline Panel PP-Statistic & $-7.211455(0.0000)$ & $-5.375084(0.0000)$ \\
\hline Panel ADF-Statistic & $-1.537465(0.0621)$ & $-0.836210(0.2015)$ \\
\hline Alternative hypothesis: individual AR coefficients (between-dimension) \\
\hline Group rho-Statistic & $1.104671(0.8653)$ & $0.532547(0.7028)$ \\
\hline Group PP-Statistic & $-8.697700(0.0000)$ & $-2.186291(0.0144)$ \\
\hline Group ADF-Statistic & $-2.664422(0.0039)$ & $0.065367(0.5261)$ \\
\hline Kao Residual Co-integration test & \\
\hline \multicolumn{3}{|c|}{ ADF- T-statistics } \\
\hline
\end{tabular}

Source: Authors computation from the output of EViews 10

\subsection{Cointegration Analysis}

The co-integration results from the Pedroni residual-based test show that for the model with intercept alone, two of the panel statistics and one for the three group statistics indicate the presence of co-integration while the other two of the group statistics and panel statistics fail to reject the null hypothesis of no co-integration. Similarly, for a model with trend and intercept, two of the test statistics and two of the group statistics indicate the presence of co-integration while the other two, Panel Rho Statistic and v-Statistic and one of the group statistics, indicate that there is no co-integration. However, these results are not robust enough to infer that cointegration exists among the variables. Following Pedroni (1999), who asserted that panel t-statistics and ADF statistics in the presence of trend and intercept are more reliable, we can presume that there is co-integration amongst the factors in the panel at a $10 \%$ level. Kao test of co-integration, on the other hand, supports a strong presence of co-integration among the variables in the panel. Therefore, there is a long-run equilibrium relationship between the logarithm of real gross domestic product per capita and services exports.

\section{Findings}

Table 5 shows the results of the cross-sectional dependency test, which shows the lack of evidence supporting the presence of cross dependency among the BINCS countries. This implies that the countries in consideration are cross-independent. Using the Panel mean Group with dynamic autoregressive distributed Lag (PMGARDL) we present the empirical estimation in Table 6.

The table shows that the empirical results are consistent with findings from the literature, howbeit at differing significance levels. Services exports are seen to have a significant positive boost on economic growth in the short run at a $5 \%$ level of significance but an insignificant boost in the long run. 
Okpeku Lilian ONOSE, Osman Nuri ARAS

Table 5. Result of Cross-sectional dependency Tests

\begin{tabular}{l|c|c|c}
\hline Test & Statistic & d.f. & Prob. \\
\hline Breusch-Pagan LM & 46.45860 & 10 & 0.1100 \\
\hline Pesaran scaled LM & 7.034357 & & 0.3660 \\
\hline Pesaran CD & 1.554189 & & 0.1201 \\
\hline
\end{tabular}

Source: Authors computation from the output of EViews 10.

Table 6. Panel Mean Group-ARDL Results

\begin{tabular}{|c|c|c|c|c|}
\hline \multicolumn{5}{|c|}{ Model: Lrgdp = f (Lsexp, Lfdi, Lgcf, Lbf) } \\
\hline \multicolumn{5}{|c|}{ Long Run Equation } \\
\hline Variable & Coefficient & Std. Error & T-Stat & P-value \\
\hline LSEXP & 0.098280 & 0.142821 & 0.688135 & 0.4932 \\
\hline LFDI & $0.732604 * * *$ & 0.267471 & 2.739000 & 0.0075 \\
\hline LGCF & $0.462232 * * *$ & 0.169095 & 2.733563 & 0.0076 \\
\hline LBF & $-2.801840^{*}$ & 1.475808 & -1.898513 & 0.0610 \\
\hline \multicolumn{5}{|c|}{ Short Run Equation } \\
\hline ECT & $-0.132262 * * *$ & 0.048836 & -2.708289 & 0.0306 \\
\hline $\mathrm{D}($ LSEXP) & 0.114792 & 0.055601 & 2.064580 & 0.0420 \\
\hline $\mathrm{D}($ LFDI) & -0.015171 & 0.014621 & -1.037607 & 0.3024 \\
\hline $\mathrm{D}(\mathrm{LGCF})$ & $0.536477 * * *$ & 0.040905 & 13.11510 & 0.0000 \\
\hline $\mathrm{D}(\mathrm{LBF})$ & -1.208708 & 0.808335 & -1.495306 & 0.1385 \\
\hline $\mathrm{C}$ & $1.028900^{* * *}$ & 1.357302 & 0.758048 & 0.4505 \\
\hline
\end{tabular}

Notes: LGDPC, LSEXP, LFDI, LGCF, and LLBF implies logarithm of gross domestic product per capita, services exports, foreign direct investment, gross capital formation, and labour force. $D$ is the first difference operator. The AIC and Hannan-Quinn were used to determine the lag lengths. ${ }^{* * *} \mathrm{p}$-value $<0.01,{ }^{* *} \mathrm{p}$ value $<0.05,{ }^{*} p$-value $<0.1$

A $1 \%$ increase in services exports generates a $0.1148 \%$ increase in economic growth on average, holding other variables constant. This aligns with the findings of Kollie (2020) and Sermcheep (2019) and suggests that services exports are a key determinant of growth in BINCS countries in the short run. The insignificant positive relationship between service export and economic growth observed in the long run aligns with the findings of Dixit and Parveen (2020). Furthermore, foreign direct investment affects economic growth significantly only in the long run at a $10 \%$ level of significance. This suggests that foreign direct investment is a long-run determinant of economic growth in BINCS countries. More specifically, a $1 \%$ increase in foreign direct investment generates an increase in economic growth by $0.732604 \%$ on average, holding other variables constant.

Moreover, findings show that gross capital formation promotes economic growth in the short run and long run. By implication, a 1\% increase in the gross capital formation increases economic growth by $0.462232 \%$ in the long run and $0.536477 \%$ in the short run at a $5 \%$ level of significance, on the average holding other variables constant. These findings suggest that investment within BINCS plays an important role in determining the level of economic growth. On the contrary, labour force drags 
economic growth in the short run and long run in BINCS countries. Although the negative effect on growth is not significant in the short run, the long-run impact is significantly alarming. This result suggests that the level of human capital development is at the elementary stage in BINCS, and effort should be put in place to ensure the refinement of the large human resources available in these countries.

\section{Conclusion and Policy Recommendations}

With increased globalization and the move of countries from import substitution to export promotion, policymakers and stakeholders have shown great concern about the possible effect the promotion of export has on economic growth. This has raised a germane question on the ELG hypothesis in recent times, given the rise in the proportion of service exports. Studies on the impact of the increase in services exports on economic growth remain scanty, especially related to the BINCS countries. Thus, the main objective of this study is to test the export-led growth hypothesis in BINCS countries, with a major interest in the service component of export. We employed the Panel mean group autoregressive distributed lag (PMG$A R D L)$ technique after conducting a preliminary test to eliminate possible limitations in the study. Findings from the study show that service exports boost economic growth in the short run. This result validates the presence of the service export-led growth hypothesis in BINCS countries in the short run. Additionally, other variables found to be an important determinant of growth in BINCS countries include gross capital formation in the short and long run and foreign direct investment, however only in short. The labour force, on the contrary, is found to drag growth in the BINCS.

By way of policy implication based on the study's findings, we suggest BINCS countries should focus more on internal investment to boost growth in the short run and long run. It is advised that this investment be channelled towards human capital investment. This is essential as an efficient labour force translates to an increase in productivity. The investment in human capital will help to refine the skills of human resources through training, increase education funding and other human capital development programs, and encourage more exportation, especially as it relates to services. Finally, since the positive effect of service export is only in the short run, we recommend the furtherance of the human capital investment, including the development of higher-skilled labour in order to increase Foreign Direct Investment, which has a positive and long-run impact on the economic growth of the economy.

Being that this is a relatively new study in emerging economies, further studies is required to place individual focus on each country in order to give adapted policy advice. Furthermore, due to the little impact of service export to the economies, there is a need for further research to be conducted on other exports and their impact on these economies. 


\section{References}

Aigheyisi, O. (2020). Does the export-led growth (ELG) hypothesis hold for services exports in Nigeria?. West African Financial and Economic Review (WAFER), 20(12), 25-60.

Aslan, A., \& Topcu, E. (2018). The relationship between export and growth: Panel data evidence from Turkish sectors. Economies, 6(2):22, 1-15. https://doi.org/10.3390/economies6020022

Awokuse, T. O. (2003). Is the export-led growth hypothesis valid for Canada? Canadian Journal of Economics / Revue Canadienne D'économique, 36(1), 126-136. https://doi.org/10.1111/1540-5982.00006

Balassa, B. (1978). Exports and economic growth: further evidence. Journal of Development Economics, 5(2), 181-189. https://doi.org/10.1016/0304-3878(78)90006-8

Balassa, B. (1985). Exports, policy choices, and economic growth in developing countries after the 1973 oil shock. Journal of Development Economics, 18(1), 23-35. https://doi.org/10.1016/0304-3878(85)90004-5

Carbaugh, R. (2015). International Economics. 15/E. Boston. Cengage Learning.

Dixit, V., \& Parveen, S. (2020). Revisiting the export-growth nexus for India: an empirical exercise. International Journal of Economic Policy in Emerging Economies, 13(5), 526-554. https://doi.org/10.1504/IJEPEE.2020.110432

Douglas, P. H. (1976). The Cobb-Douglas production function once again: its history, its testing, and some new empirical values. Journal of Political Economy, 84(5), 903-915. https://doi.org/10.1086/260489

Feddersen, M., Nel, H., \& Botha, F. (2017). Exports, capital formation and economic growth in South Africa. African Review of Economics and Finance, 9(1), 213-244.

Helpman, E., \& Krugman, P. R. (1985). Market structure and foreign trade: Increasing returns, imperfect competition, and the international economy. MIT Press.

Islam, M. (2020). Testing Export-led Growth Hypothesis: Evidence from BCIM Countries. Testing Export-led Growth Hypothesis: Evidence from BCIM Countries. SSRN Paper. https://doi.org/10.2139/ssrn.3616609

Iyabo, A. (2020). The impact of non-oil exports on economic growth in Nigeria. Al-Hikmah Journal of Education, 7(2), 67-73.

Kalaitzi, A., \& Chamberlain, T. (2020). The validity of the export-led growth hypothesis: some evidence from the GCC. The Journal of International Trade \& Economic Development, 30(2), 224-245. https://doi.org/10.1080/09638199.2020.1813191

Kalaitzi, A. S., \& Cleeve, E. (2018). Export-led growth in the UAE: multivariate causality between primary exports, manufactured exports and economic growth. Eurasian Business Review, 8(3), 341-365. https://doi.org/10.1007/s40821-017-0089-1

Kappa, K. (2020). Do the vegetable exports lead to economic growth? An empirical evidence in selected SAARC economies. Journal of Public Affairs. https://doi.org/10.1002/pa.2484

Kollie, G. (2020). Export-Led Growth Hypothesis in ECOWAS: A Panel Data Analysis. African Journal of Economic Review, 8(2), 258-275.

Odhiambo, N. M. (2021). Is export-led growth hypothesis still valid for sub-Saharan African countries? New evidence from panel data analysis. European Journal of Management and Business Economics. https://doi.org/10.1108/EJMBE-06-2020-0156 
Does the Export-Led Growth Hypothesis Hold for Services Exports in Emerging Economies?

Pedroni, P. (1999). Critical values for cointegration tests in heterogeneous panels with multiple regressors. Oxford Bulletin of Economics and statistics, 61(S1), 653-670. https://doi.org/10.1111/1468-0084.61.s1.14

Pesaran, M.H., Shin, Y. and Smith, R.J., 2001. Bounds Testing Approaches to The Analysis of Level Relationships. Journal of Applied Econometrics, 16(13), 289-326. https://doi.org/10.1002/iae.616

Priyankara, E. (2018). Services exports and economic growth in Sri Lanka: does the export-led growth hypothesis hold for services exports? Journal of Service Science and Management, 11(04), 479-495. https://doi.org/10.4236/issm.2018.114033

Sermcheep, S. (2019). Services export and economic growth in ASEAN countries. Journal of Asian Economic Integration, 1(2), 163-182. https://doi.org/10.1177/2631684619883443

Seyram Asafo, S. (2020). Export-led growth hypothesis for Ghana: A TVAR \& TVECM Analysis. The Economics and Finance Letters, 7(2), 92-103. https://doi.org/10.18488/journal.29.2020.72.92.103

Shieh, C. H. (2020). Services export and economic growth: a panel cointegration approach. International Journal of Business and Economics, 5(2), 66-82.

Taban, S., \& Aktar, I. (2008). An empirical examination of the export-led growth hypothesis in Turkey. Journal of Yaşar University, 3(11), 1535-1551.

Van der Marel, E. (2012). Trade in services and TFP: the role of regulation. The World Economy, 35(11), 1530-1558. https://doi.org/10.1111/twec.12004

World Development Indicators. (2021). Databank. databank.worldbank.org. (2021). http://databank.worldbank.org/reports.aspx?source=World-Development-Indicators 